\title{
An Overview of Late-onset Rheumatoid Arthritis
}

\author{
Deniz EVCİK \\ Editor-in-Chief
}

It is well known that rheumatoid arthritis (RA) has an increased incidence in young and middle-aged adults. When this disease begins in adults between the ages of 60 and 65, it is accepted as late-onset RA (LORA), which occurs at a rate of $2 \% .{ }^{[1]}$

In recent years, rheumatologists have focused on the diagnosis and treatment of early-onset RA (EORA) in order to prevent joint erosion. Diagnosing LORA has also proven to be somewhat difficult because of the overlapping clinical features of these two types of RA. However, LORA differs clinically from EORA in some important ways. In addition, LORA also has similar presentations to other diseases, such as polymyalgia rheumatica (PMR) ${ }^{[2]}$ In the past, this type of RA was known to be less destructive and had a better prognosis. Recent studies have differentiated between the clinical and laboratory features of EORA and LORA, and although there are some contradictions involving various parameters, such as morning stiffness, the presence of autoantibodies and the anti-CCP levels are similar. ${ }^{[2-5]}$

As previously mentioned, there are clinical differences between LORA and EORA. For example, the majority of LORA patients have an acute onset, and instead of classical joint involvement, mostly large joints like the shoulders are initially affected. Additionally, they also have systemic symptoms, including fever, myalgia, and weight loss as well as symptoms that mimic PMR. Another reason that it is not easy to differentiate between LORA and PMR is that the laboratory findings for both include higher C-reactive protein (CRP) and erythrocyte sedimentation rate (ESR) levels along with higher levels of anemia. However, the radiological scores seem to be higher for LORA than EORA, and these are correlated with articular damage.

The use of disease-modifying antirheumatic drugs (DMARDs), biologics, or combination therapies are lower with LORA patients compared with those with EORA. In addition, the methotrexate doses are also lower in patients with LORA while the rate of discontinuation of this drug is higher in EORA patients. ${ }^{[6]}$ Furthermore, there is difficulty in managing drug therapy in elderly patients because of polypharmacy.

The most important item to monitor in making a distinction between LORA and EORA is the functional level of the late-onset patients since they have greater disability levels and higher functional impairment. ${ }^{[7]}$ Moreover, most LORA patients also have comorbid diseases and additional inflammatory diseases that increase the level of functional impairment, which was already not acceptable. Rheumatoid arthritis mostly coexists with osteoarthritis (OA), and both decrease the quality of life (QoL). Furthermore, increased disability is associated with getting older and being a female. Finally, whether or not a patient with LORA has a poor prognosis depends on multiple factors; therefore, one of the main goals should be to improve the physical capacity and provide good QoL for these patients. Hence, those afflicted with LORA need more rheumatological rehabilitation programs that include the use of assistive devices, physical therapy and analgesic modalities, exercise programs, aquatherapy, and balance exercises. In addition, large study groups are needed with long-term follow-up results. Furthermore, the development of an arthritis registry system might also be helpful for collecting the data from any future studies.

\footnotetext{
Correspondence: Deniz Evcik, M.D. Ufuk Üniversitesi Tıp Fakültesi, Fiziksel Tıp ve Rehabilitasyon Anabilim Dalı, 06520 Balgat, Ankara, Turkey. Tel: +90 312 - 2044351 e-mail: evcikd@yahoo.com 


\section{Declaration of conflicting interests}

The author declared no conflicts of interest with respect to the authorship and/or publication of this article.

\section{Funding}

The author received no financial support for the research and/or authorship of this article.

\section{REFERENCES}

1. Villa-Blanco JI, Calvo-Alén J. Elderly onset rheumatoid arthritis: differential diagnosis and choice of first-line and subsequent therapy. Drugs Aging 2009;26:739-50. doi: 10.2165/11316740-000000000-00000.

2. Goğüş F.Yaşlı başlangıçlı romatoid artrit: Klinik özellikleri ve ayırıcı tanısı. Turkish Journal of Geriatrics 2005;8:153-7.

3. El-Labban AS, Omar HA, El-Shereif RR, Ali F, El-Mansoury TM. Pattern of young and old onset rheumatoid arthritis (YORA and EORA) among a group of egyptian patients with rheumatoid arthritis. Clin Med Insights Arthritis Musculoskelet Disord 2010;3:25-31.

4. Turkcapar N, Demir O, Atli T, Kopuk M, Turgay M, Kinikli G, et al. Late onset rheumatoid arthritis: clinical and laboratory comparisons with younger onset patients. Arch Gerontol Geriatr 2006;42:225-31.

5. Calvo-Alén J, Corrales A, Sánchez-Andrada S, FernándezEchevarría MA, Peña JL, Rodríguez-Valverde V. Outcome of late-onset rheumatoid arthritis. Clin Rheumatol 2005;24:485-9.

6. Bernatsky S, Ehrmann Feldman D. Discontinuation of methotrexate therapy in older patients with newly diagnosed rheumatoid arthritis: analysis of administrative health databases in Québec, Canada. Drugs Aging 2008;25:879-84.

7. Camacho EM, Verstappen SM, Lunt M, Bunn DK, Symmons DP. Influence of age and sex on functional outcome over time in a cohort of patients with recentonset inflammatory polyarthritis: results from the Norfolk Arthritis Register. Arthritis Care Res (Hoboken) 2011;63:1745-52. doi: 10.1002/acr.20609. 